\title{
Inspired Learning in the Library
}

\author{
Leonie Mcllvenny \\ Iona Presentation College \\ 33 Palmerston St, Mosman Park, WA 6012 \\ Australia \\ Imcilvenny@iona.wa.edu.au
}

\begin{abstract}
Re-visioning the library for the $21^{\text {st }}$ century
The iCentre at lona Presentation College has created a unique program that merges the traditional aspects of information literacy, study skills and critical and creative thinking into a holistic program. It traverses all year levels and embraces various learning groups and curriculum support programs. Using the library program as the foundation and technology as a key delivery platform, this initiative attempts to ensure that every student in the school not only receives ongoing opportunities to master skills and knowledge considered essential for 21st century learners, but also develops the cognitive and affective predispositions towards learning, personal development, self-efficacy and accountability.
\end{abstract}

Keywords: Information literacy, efficacy, leadership, transformation, inspiration

\section{Introduction}

At the beginning of 2012 the lona College library reviewed its policies, procedures, and strategies against key indicators articulated in Learning for the Future (2001), the principle authoritative guide for school libraries in Australia for the last decade. The library program addressed each of the five prescribed domains:

- Learners and learning

- Teachers and teaching

- Resourcing the curriculum

- Facilitating access to information

- Developing the physical environment.

As a result of this audit the library was confident that performance indicators in each domain were being adequately addressed. Digital resources were part of the library collection; the automated library system provided federated searching of not only the traditional resources but also online databases, and teachers were supported in their curriculum program through pathfinders and collaborative teaching of research-based lessons. All English classes from Year Seven to Year Ten attended the library on a regular basis for literature promotion and reading.

What started as a general review, however, evolved into a major restructure as internal and external drivers demanded a more comprehensive examination of the library's role in the College that went beyond these five domains. The proposal for a new iCentre (as part of a major building project), library staff changes, a one-to-one laptop program, and the new Australian Curriculum all became catalysts for re-visioning the future direction of the library. This meant a paradigm shift in the way the library not only served the educational needs of the school community but how it would became a compass in supporting the school's curriculum innovation as well. 


\section{Stage One - The Integrated Information Literacy Plan}

Not only was it necessary to review existing practices against a recognised series of performance indicators (Learning for the Future, 2001), it was also essential the change process was informed by current thinking about $21^{\text {st }}$ century school libraries. Extensive research resulted in the following documents playing a pivotal role in the development of the Integrated Information Literacy Plan - Stage One in the re-visioning process from library to iCentre.

The Melbourne Declaration on Educational Goals for Young Australians identifies essential skills for twenty-first century learners in literacy, numeracy, information and communication technology (ICT), thinking, creativity, teamwork and communication. Goal Two describes individuals who are creative and productive users of technology, especially ICT, as a foundation of success in all learning areas, and who can develop their capacity to learn and play an active role in their own learning (MCEETYA, 2005, p. 9).

Coupled with this, the importance of ICT in society is emphasised in the paper Enabling Our Future, a document that identifies ICT literate citizens as being central to Australia's economic and social goals. The importance of ICT in schooling was also reinforced by the MCEETYA Performance Measurement and Reporting Taskforce (2005) that adopted a definition of ICT Literacy as:

"The ability of individuals to use ICT appropriately to access, manage and evaluate information, develop new understandings, and communicate with others in order to participate effectively in society" (MCEETYA, 2005, vii).

More directly within the newly mandated Australian Curriculum, the General Capabilities encompass the knowledge, skills, behaviors and dispositions that, together with curriculum content in each learning area and the cross-curriculum priorities, will assist students to live and work successfully in the twenty-first century (Australian Curriculum, 2011). Critical and Creative Thinking and ICT Capabilities are two of the General Capabilities that, not only support the Melbourne Declaration, they also align with the development of information literacy.

In the international arena UNESCO (2008) and ISTE both suggest that information literacy is essential to enable people to utilize vast quantities of information and communication technology. In this context, information literacy has become a new paradigm in the information and communication landscape. Understanding technologies is not enough. Students and teachers must engage with these diverse technologies efficiently and effectively to search for, retrieve, organize, analyze, and evaluate information. They then need to use the gathered information for specific decision-making and problem-solving activities. (UNESCO, 2008).

At a National level the Australian Library and Information Society, (2003) suggests that for Australia to be a global culture, economy and democracy it must provide a workforce that are able to recognise the need for information, and identify, locate, access, evaluate and apply the needed information. (ALIA, 2003).

The Australian and New Zealand Institute further support this. They developed a framework with six core standards that identify an information literate person as one who recognizes the need for information and determines the nature and extent of the information needed; finds that needed information effectively and efficiently; critically evaluates information and the information seeking process; manages information collected; organizes and synthesizes that information to create new ideas and knowledge; and uses information with understanding and acknowledges cultural, ethical, legal, and social issues surrounding the use of information. 
Acknowledging the importance of the 'skills for the $21^{\text {st }}$ century' was not enough to springboard the evolution of the library to the new iCentre. What was needed was a clearly articulated 'plan of action' that embraced the above-mentioned visionary policies, statements, and frameworks and translated them into practical educational outcomes aligned with the school's goals and mission statement. If the iCentre was to play a significant role in the curriculum delivery in the school then it required a program that provided high-stakes deliverables that could be measured as part of an evidence-based practice methodology. The Integrated Information Literacy Plan (hereafter The Plan) was the response to this need.

\section{Starting with an information skills framework}

Teacher Librarians have championed the development of information literacy skills for many years, albeit often unsupported and in isolation in their schools. This seemed the most logical place to start the re-visioning process for the iCentre. While there are numerous models for the development of Information Literacy, the Information Process has been a framework widely accepted and used in Australian Schools and the one that had been adopted at lona. The question was whether this Framework was still relevant in light of the new Australian Curriculum.

A mapping exercise was undertaken where the Information Process was aligned with key inquiry-based skills from the Australian Curriculum, namely two of the seven General Capabilities; Critical and Creative Thinking and ICT Capability (Figures 1 and 2). and the learning area process strands Science Inquiry Skills and Historical Skills (Table 1).

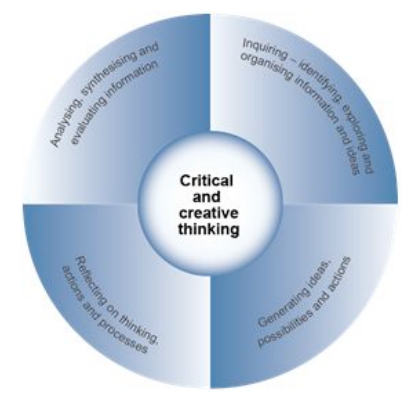

Figure 1: The Organisational Framework of the Critical and Creative Thinking General Capability @ Australian Curriculum, Assessment and Reporting Authority (2011)

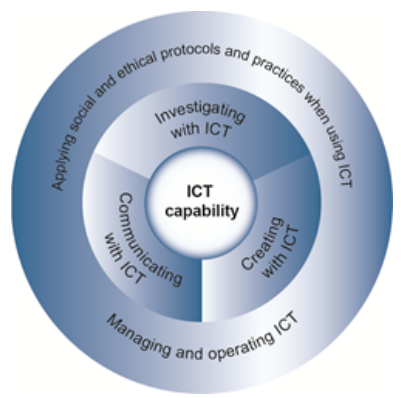

Figure 2: The Organisational Framework of the ICT Capability General Capability (C) Australian Curriculum, Assessment and Reporting Authority (2011)

The main purpose of this exercise was to reassure teachers that while using the Information Process framework as the foundation for inquiry learning in the school, mandated curriculum outcomes were also being addressed. 
Table 1: Comparison of the Information Process Stages and the Organizing Elements from the ICT Capability and Critical and Creative Thinking General Capability, and Learning Area Process Strands (Mcllvenny, 2013)

\begin{tabular}{|c|c|c|c|c|c|}
\hline & \multicolumn{2}{|c|}{ General Capabilities } & \multicolumn{3}{|c|}{ Learning Area Process Strands } \\
\hline $\begin{array}{c}\text { The } \\
\text { Information } \\
\text { Process }\end{array}$ & $\begin{array}{l}\text { Critical and } \\
\text { creative } \\
\text { thinking }\end{array}$ & $\begin{array}{c}\text { ICT } \\
\text { Capabilities }\end{array}$ & $\begin{array}{l}\text { Historical } \\
\text { Skills }\end{array}$ & $\begin{array}{c}\text { Science } \\
\text { Inquiry } \\
\text { Skills }\end{array}$ & Literacy \\
\hline Defining & $\begin{array}{l}\text { Inquiring - } \\
\text { identifying, } \\
\text { exploring } \\
\text { and } \\
\text { organizing }\end{array}$ & $\begin{array}{l}\text { Investigating } \\
\text { with ICT }\end{array}$ & $\begin{array}{l}\text { Historical } \\
\text { questions } \\
\text { and research }\end{array}$ & $\begin{array}{l}\text { Questioning } \\
\text { and } \\
\text { predicting }\end{array}$ & $\begin{array}{l}\text { Language - } \\
\text { expressing } \\
\text { and } \\
\text { developing } \\
\text { ideas }\end{array}$ \\
\hline Locating & $\begin{array}{l}\text { information } \\
\text { and ideas. }\end{array}$ & & $\begin{array}{l}\text { Historical } \\
\text { questions } \\
\text { and research }\end{array}$ & $\begin{array}{l}\text { Planning and } \\
\text { conducting }\end{array}$ & $\begin{array}{l}\text { Literacy - } \\
\text { texts in } \\
\text { context }\end{array}$ \\
\hline Selecting & $\begin{array}{l}\text { Analyzing, } \\
\text { synthesizing } \\
\text { and }\end{array}$ & & $\begin{array}{l}\text { Analysis and } \\
\text { use of } \\
\text { sources }\end{array}$ & $\begin{array}{l}\text { Planning and } \\
\text { conducting }\end{array}$ & $\begin{array}{l}\text { Literacy - } \\
\text { texts in } \\
\text { context }\end{array}$ \\
\hline $\begin{array}{l}\text { Organizing } \\
\text { and } \\
\text { processing }\end{array}$ & $\begin{array}{l}\text { evaluating } \\
\text { information }\end{array}$ & $\begin{array}{l}\text { Creating with } \\
\text { ICT } \\
\text { Communicati } \\
\text { ng with ICT }\end{array}$ & $\begin{array}{l}\text { Analysis and } \\
\text { use of } \\
\text { sources / } \\
\text { Perspectives } \\
\text { and } \\
\text { interpretation } \\
\text { s }\end{array}$ & $\begin{array}{l}\text { Processing } \\
\text { and } \\
\text { analyzing } \\
\text { data and } \\
\text { information }\end{array}$ & $\begin{array}{l}\text { Literacy - } \\
\text { Interpreting, } \\
\text { analyzing, } \\
\text { evaluating } \\
\text { Literacy - } \\
\text { Creating } \\
\text { texts } \\
\text { Literature - } \\
\text { Creating } \\
\text { Literature }\end{array}$ \\
\hline Presenting & $\begin{array}{l}\text { Generating } \\
\text { ideas, } \\
\text { possibilities } \\
\text { and actions }\end{array}$ & & $\begin{array}{l}\text { Explanation } \\
\text { and } \\
\text { communicati } \\
\text { on }\end{array}$ & $\begin{array}{l}\text { Communicati } \\
\text { ng }\end{array}$ & $\begin{array}{l}\text { Literature } \\
\text { Responding } \\
\text { to literature } \\
\text { Literacy - } \\
\text { Creating } \\
\text { texts } \\
\text { Literacy - } \\
\text { interacting } \\
\text { with others } \\
\end{array}$ \\
\hline Evaluating & $\begin{array}{l}\text { Reflecting on } \\
\text { thinking, } \\
\text { actions and } \\
\text { processes. }\end{array}$ & $\begin{array}{l}\text { Applying } \\
\text { social and } \\
\text { ethical } \\
\text { protocols } \\
\text { and practices } \\
\text { when using } \\
\text { ICT }\end{array}$ & & Evaluating & \\
\hline
\end{tabular}

From framework to scope and sequence

Not only is a commitment by learning areas and teachers to explicitly teach these skills essential, a developmental approach is necessary to ensure students receive repeated opportunities to practice these skills at increasing levels of complexity. This requires a commitment from all staff and learning areas to ensure information skills mapped to a scope and sequence chart are strategically embedded in the curriculum being taught. The initial mapping task (Table 1) was further developed across the levels and years as outlined in the Australian Curriculum. What resulted was a series of 'maps' that identified explicitly where 
these skills were to be taught across a range of learning areas. Table 2 describes one such mapping exercise.

Table 2. Identifying Elements from the Critical and Ceative Thinking General Capability Learning Continuum (C) Australian Curriculum, Assessment \& reporting Authority 2011 that relate to the Information Process (Mcllvenny, 2013)

\begin{tabular}{|c|c|c|c|c|c|}
\hline Level 1 & $\begin{array}{l}\text { Level } 2 \\
\end{array}$ & Level 3 & Level 4 & Level 5 & Level 6 \\
\hline \multicolumn{6}{|c|}{ Inquiring - identifying, exploring and organising information and ideas } \\
\hline \multicolumn{6}{|c|}{ Pose questions } \\
\hline $\begin{array}{l}\text { Pose } \\
\text { factual and } \\
\text { exploratory } \\
\text { questions } \\
\text { based on } \\
\text { personal } \\
\text { interests } \\
\text { and } \\
\text { experiences }\end{array}$ & $\begin{array}{l}\text { Pose } \\
\text { questions to } \\
\text { identfy and } \\
\text { clarify isues, } \\
\text { and compare } \\
\text { information in } \\
\text { their world }\end{array}$ & $\begin{array}{l}\text { Pose } \\
\text { questions to } \\
\text { expand their } \\
\text { knowledge } \\
\text { about the } \\
\text { world. }\end{array}$ & $\begin{array}{l}\text { Pose } \\
\text { questions to } \\
\text { clarify and } \\
\text { interpret } \\
\text { information } \\
\text { and probe for } \\
\text { causes and } \\
\text { consequence } \\
\text { s }\end{array}$ & $\begin{array}{l}\text { Pose } \\
\text { questions to } \\
\text { probe } \\
\text { assumptions } \\
\text { and } \\
\text { investigate } \\
\text { complex } \\
\text { issues }\end{array}$ & $\begin{array}{l}\text { Pose } \\
\text { questions to } \\
\text { critically } \\
\text { analyse } \\
\text { complex } \\
\text { issues and } \\
\text { abtract } \\
\text { ideas }\end{array}$ \\
\hline \multicolumn{6}{|c|}{ Identify and clarify information and ideas } \\
\hline $\begin{array}{l}\text { Identify and } \\
\text { describe } \\
\text { familiar } \\
\text { information } \\
\text { and ideas } \\
\text { during a } \\
\text { discussion } \\
\text { or } \\
\text { investigatio } \\
n\end{array}$ & $\begin{array}{l}\text { Identify and } \\
\text { explore } \\
\text { information } \\
\text { and ideas } \\
\text { from source } \\
\text { materials }\end{array}$ & $\begin{array}{l}\text { Identify main } \\
\text { ideas and } \\
\text { select and } \\
\text { clarify } \\
\text { information } \\
\text { from a range } \\
\text { of sources. }\end{array}$ & $\begin{array}{l}\text { Identify and } \\
\text { clraify } \\
\text { relevant } \\
\text { information } \\
\text { and prioritise } \\
\text { ideas. }\end{array}$ & $\begin{array}{l}\text { Clarify } \\
\text { information } \\
\text { and ideas } \\
\text { from texts or } \\
\text { images when } \\
\text { exploring } \\
\text { challenging } \\
\text { issues. }\end{array}$ & $\begin{array}{l}\text { Clarify } \\
\text { complex } \\
\text { information } \\
\text { and ideas } \\
\text { drawn from } \\
\text { a range of } \\
\text { sources. }\end{array}$ \\
\hline \multicolumn{6}{|c|}{ Organise and process information } \\
\hline $\begin{array}{l}\text { Gather } \\
\text { similar } \\
\text { information } \\
\text { or } \\
\text { depictions } \\
\text { from given } \\
\text { sources }\end{array}$ & $\begin{array}{l}\text { Organise } \\
\text { information } \\
\text { based on } \\
\text { similar or } \\
\text { relevant } \\
\text { ideas from } \\
\text { several } \\
\text { sources. }\end{array}$ & $\begin{array}{l}\text { Collect, } \\
\text { compare and } \\
\text { categorise } \\
\text { facts and } \\
\text { opinions } \\
\text { found in a } \\
\text { widening } \\
\text { range of } \\
\text { sources. }\end{array}$ & $\begin{array}{l}\text { Analyse, } \\
\text { condense } \\
\text { and combine } \\
\text { relevant } \\
\text { information } \\
\text { from multiple } \\
\text { sources. }\end{array}$ & $\begin{array}{l}\text { Critically } \\
\text { analyse } \\
\text { information } \\
\text { and evidence } \\
\text { according to } \\
\text { criteria such } \\
\text { as validity } \\
\text { and } \\
\text { relevance. }\end{array}$ & $\begin{array}{l}\text { Critically } \\
\text { analyse } \\
\text { independen } \\
\text { tly sourced } \\
\text { information } \\
\text { to } \\
\text { determine } \\
\text { bias and } \\
\text { reliability. }\end{array}$ \\
\hline \multicolumn{6}{|c|}{ Generating ideas, possibilities and actions } \\
\hline \multicolumn{6}{|c|}{ Imagine possibilities and connect ideas } \\
\hline $\begin{array}{l}\text { Use } \\
\text { imagination } \\
\text { to view or } \\
\text { create } \\
\text { things in } \\
\text { new ways } \\
\text { and connect } \\
\text { to things } \\
\text { that seem } \\
\text { different. }\end{array}$ & $\begin{array}{l}\text { Build on what } \\
\text { they know to } \\
\text { create ideas } \\
\text { and } \\
\text { possibilities } \\
\text { in ways that } \\
\text { are new to } \\
\text { them. }\end{array}$ & $\begin{array}{l}\text { Expand on } \\
\text { known ideas } \\
\text { to create new } \\
\text { and } \\
\text { imaginative } \\
\text { combinations }\end{array}$ & $\begin{array}{l}\text { Combine } \\
\text { ideas in a } \\
\text { variety of } \\
\text { ways and } \\
\text { from a range } \\
\text { of sources to } \\
\text { create new } \\
\text { possibilities. }\end{array}$ & $\begin{array}{l}\text { Draw } \\
\text { parallels } \\
\text { between } \\
\text { known and } \\
\text { new ideas to } \\
\text { create new } \\
\text { ways of } \\
\text { achieving } \\
\text { goals. }\end{array}$ & $\begin{array}{l}\text { Create and } \\
\text { connect } \\
\text { complex } \\
\text { ideas using } \\
\text { imagery, } \\
\text { analogies } \\
\text { and } \\
\text { symbolism. }\end{array}$ \\
\hline \multicolumn{6}{|c|}{ Consider alternatives } \\
\hline Suggest & Identify and & Explore & Identify & Generate & Speculate \\
\hline
\end{tabular}




\begin{tabular}{|c|c|c|c|c|c|}
\hline $\begin{array}{l}\text { alternative } \\
\text { and creative } \\
\text { ways to } \\
\text { approach a } \\
\text { given } \\
\text { situation or } \\
\text { task. }\end{array}$ & $\begin{array}{l}\text { compare } \\
\text { creatve ideas } \\
\text { to think } \\
\text { broadly about } \\
\text { a given } \\
\text { situtaion or } \\
\text { problem. }\end{array}$ & $\begin{array}{l}\text { situations } \\
\text { using } \\
\text { creative } \\
\text { thinking } \\
\text { strategies to } \\
\text { propose a } \\
\text { range of } \\
\text { alternatives. }\end{array}$ & $\begin{array}{l}\text { situations } \\
\text { where } \\
\text { current } \\
\text { approaches } \\
\text { do not work, } \\
\text { challenge } \\
\text { existing ideas } \\
\text { and generate } \\
\text { alternative } \\
\text { solutions. }\end{array}$ & $\begin{array}{l}\text { alternatives } \\
\text { and } \\
\text { innovative } \\
\text { solutions, } \\
\text { and adapt } \\
\text { ideas, } \\
\text { including } \\
\text { when } \\
\text { information is } \\
\text { limited or } \\
\text { conflcting. }\end{array}$ & $\begin{array}{l}\text { on creative } \\
\text { options to } \\
\text { modify } \\
\text { ideas when } \\
\text { circumstanc } \\
\text { es change. }\end{array}$ \\
\hline \multicolumn{6}{|c|}{ Seek solutions and put ideas into action } \\
\hline $\begin{array}{l}\text { Predict } \\
\text { what might } \\
\text { happen in a } \\
\text { given } \\
\text { situation } \\
\text { and when } \\
\text { putting } \\
\text { ideas into } \\
\text { action }\end{array}$ & $\begin{array}{l}\text { Investigate } \\
\text { options and } \\
\text { predict } \\
\text { possible } \\
\text { outcomes } \\
\text { when putting } \\
\text { ideas into } \\
\text { action. }\end{array}$ & $\begin{array}{l}\text { Experiment } \\
\text { with a range } \\
\text { of options } \\
\text { when } \\
\text { seeking } \\
\text { solutions and } \\
\text { putting ideas } \\
\text { into action. }\end{array}$ & $\begin{array}{l}\text { Assess and } \\
\text { test options } \\
\text { to identify the } \\
\text { most } \\
\text { effective } \\
\text { solution and } \\
\text { put ideas into } \\
\text { action. }\end{array}$ & $\begin{array}{l}\text { Predict } \\
\text { possibilities, } \\
\text { and identify } \\
\text { and test } \\
\text { consequence } \\
\text { s when } \\
\text { seeking } \\
\text { solutions and } \\
\text { puttng ideas } \\
\text { into action. }\end{array}$ & $\begin{array}{l}\text { Assess } \\
\text { risks and } \\
\text { explain } \\
\text { contingenci } \\
\text { es, taking } \\
\text { account of a } \\
\text { range of } \\
\text { perspective } \\
\text { s, when } \\
\text { seeking } \\
\text { solutions } \\
\text { and putting } \\
\text { complex } \\
\text { issues into } \\
\text { action. }\end{array}$ \\
\hline \multicolumn{6}{|c|}{ Reflecting on thinking processes } \\
\hline \multicolumn{6}{|c|}{ Think about thinking } \\
\hline $\begin{array}{l}\text { Describe } \\
\text { what they } \\
\text { are thinking } \\
\text { and give } \\
\text { reasons } \\
\text { why }\end{array}$ & $\begin{array}{l}\text { Describe the } \\
\text { thinking } \\
\text { strategies } \\
\text { used in given } \\
\text { situations } \\
\text { and tasks. }\end{array}$ & $\begin{array}{l}\text { Reflect on, } \\
\text { explain, and } \\
\text { check } \\
\text { processes } \\
\text { used to come } \\
\text { to } \\
\text { conclusions. }\end{array}$ & $\begin{array}{l}\text { Reflect on } \\
\text { assumptions } \\
\text { made, } \\
\text { consider } \\
\text { reasonable } \\
\text { criticsm, and } \\
\text { adjust their } \\
\text { thinking if } \\
\text { necessary. }\end{array}$ & $\begin{array}{l}\text { Assess } \\
\text { assumptions } \\
\text { in their } \\
\text { thinking and } \\
\text { invite } \\
\text { alternative } \\
\text { opinions. }\end{array}$ & $\begin{array}{l}\text { Give } \\
\text { reasons to } \\
\text { support } \\
\text { their } \\
\text { thinking, } \\
\text { and } \\
\text { address } \\
\text { opposing } \\
\text { viewpoints } \\
\text { and } \\
\text { possible } \\
\text { weaknesse } \\
\text { s in their } \\
\text { positions. }\end{array}$ \\
\hline \multicolumn{6}{|c|}{ Reflect on processes } \\
\hline $\begin{array}{l}\text { Identify the } \\
\text { main } \\
\text { elements of } \\
\text { the steps in } \\
\text { a thinking } \\
\text { process. }\end{array}$ & $\begin{array}{l}\text { Outline the } \\
\text { details and } \\
\text { sequence in } \\
\text { a whole task } \\
\text { and separate } \\
\text { it into } \\
\text { workable } \\
\text { parts. }\end{array}$ & $\begin{array}{l}\text { Identify } \\
\text { pertinent } \\
\text { information in } \\
\text { an } \\
\text { investigation } \\
\text { and separate } \\
\text { into smaller } \\
\text { parts or } \\
\text { ideas. }\end{array}$ & $\begin{array}{l}\text { Identify and } \\
\text { adjust the } \\
\text { thinking } \\
\text { beind } \\
\text { choices they } \\
\text { have made. }\end{array}$ & $\begin{array}{l}\text { Evaluate and } \\
\text { justify the } \\
\text { reasons } \\
\text { behind } \\
\text { choosing a } \\
\text { particular } \\
\text { problem- } \\
\text { solving } \\
\text { strategy }\end{array}$ & $\begin{array}{l}\text { Balance } \\
\text { rational and } \\
\text { irrational } \\
\text { components } \\
\text { of a } \\
\text { complex or } \\
\text { ambiguous } \\
\text { problem to } \\
\text { evaluate } \\
\text { evidence. }\end{array}$ \\
\hline
\end{tabular}




\begin{tabular}{|c|c|c|c|c|c|}
\hline \multicolumn{6}{|c|}{ Transfer knowledge into new contexts } \\
\hline $\begin{array}{l}\text { Connect } \\
\text { information } \\
\text { from one } \\
\text { setting to } \\
\text { another. }\end{array}$ & $\begin{array}{l}\text { Use } \\
\text { information } \\
\text { from a } \\
\text { previous } \\
\text { experience to } \\
\text { inform a new } \\
\text { idea. }\end{array}$ & $\begin{array}{l}\text { Transfer and } \\
\text { apply } \\
\text { information in } \\
\text { one setting to } \\
\text { enrich } \\
\text { another. }\end{array}$ & $\begin{array}{l}\text { Apply } \\
\text { knowledge } \\
\text { gained from } \\
\text { one context } \\
\text { to another } \\
\text { unrelated } \\
\text { context and } \\
\text { identify new } \\
\text { meaning }\end{array}$ & $\begin{array}{l}\text { Justify } \\
\text { reasons for } \\
\text { decisions } \\
\text { when } \\
\text { transferring } \\
\text { information to } \\
\text { similar and } \\
\text { different } \\
\text { contexts. }\end{array}$ & $\begin{array}{l}\text { Identify, } \\
\text { plan and } \\
\text { justify } \\
\text { transferenc } \\
\text { e of } \\
\text { knowledge } \\
\text { to new } \\
\text { contexts. }\end{array}$ \\
\hline \multicolumn{6}{|c|}{ Analysing, synthesising and evaluating reasoning and procedures } \\
\hline \multicolumn{6}{|c|}{ Apply logic and reasoning } \\
\hline $\begin{array}{l}\text { Identify the } \\
\text { thinking } \\
\text { used to } \\
\text { solve } \\
\text { problems in } \\
\text { a given } \\
\text { situtaion. }\end{array}$ & $\begin{array}{l}\text { Identify } \\
\text { reasoning } \\
\text { used in } \\
\text { choices or } \\
\text { actions in } \\
\text { specific } \\
\text { situations. }\end{array}$ & $\begin{array}{l}\text { Identify and } \\
\text { apply } \\
\text { appropriate } \\
\text { reasoning } \\
\text { and thinking } \\
\text { strategies for } \\
\text { particular } \\
\text { outcomes. }\end{array}$ & $\begin{array}{l}\text { Assess } \\
\text { whether } \\
\text { there is } \\
\text { adequate } \\
\text { reasoning } \\
\text { and evidence } \\
\text { to justify a } \\
\text { claim, } \\
\text { conclusion or } \\
\text { outcome. }\end{array}$ & $\begin{array}{l}\text { Identify gaps } \\
\text { in reasoning } \\
\text { and missing } \\
\text { elements in } \\
\text { information. }\end{array}$ & $\begin{array}{l}\text { Analayse } \\
\text { reasoning } \\
\text { used in } \\
\text { finding and } \\
\text { applying } \\
\text { solutions, } \\
\text { and in } \\
\text { choice of } \\
\text { resources. }\end{array}$ \\
\hline \multicolumn{6}{|c|}{ Draw conclusions and design a course of action } \\
\hline $\begin{array}{l}\text { Share their } \\
\text { thinking } \\
\text { about } \\
\text { possible } \\
\text { courses of } \\
\text { action }\end{array}$ & $\begin{array}{l}\text { Identify } \\
\text { alternative } \\
\text { courses of } \\
\text { action or } \\
\text { possible } \\
\text { conclusions } \\
\text { when } \\
\text { presented } \\
\text { with new } \\
\text { information. }\end{array}$ & $\begin{array}{l}\text { Draw on prior } \\
\text { knowledge } \\
\text { and use } \\
\text { evidence } \\
\text { when } \\
\text { choosing a } \\
\text { course of } \\
\text { action or } \\
\text { drawing a } \\
\text { conclusion. }\end{array}$ & $\begin{array}{l}\text { Scrutinise } \\
\text { ideas and } \\
\text { concepts, } \\
\text { test } \\
\text { conclusions } \\
\text { and modify } \\
\text { actions when } \\
\text { designing a } \\
\text { course of } \\
\text { action. }\end{array}$ & $\begin{array}{l}\text { Differentate } \\
\text { components } \\
\text { of a designed } \\
\text { course of } \\
\text { action and } \\
\text { tolerate } \\
\text { ambiguities } \\
\text { when } \\
\text { drawing } \\
\text { conclusions. }\end{array}$ & $\begin{array}{l}\text { Use logical } \\
\text { \& abstract } \\
\text { thinking to } \\
\text { analyse and } \\
\text { synthesise } \\
\text { complex } \\
\text { information } \\
\text { to inform a } \\
\text { course of } \\
\text { action. }\end{array}$ \\
\hline \multicolumn{6}{|c|}{ Evaluate procedures and outcomes } \\
\hline $\begin{array}{l}\text { Check } \\
\text { whether } \\
\text { they are } \\
\text { satisfied } \\
\text { with the } \\
\text { outcome of } \\
\text { tasks or } \\
\text { actions. }\end{array}$ & $\begin{array}{l}\text { Evaluate } \\
\text { whether they } \\
\text { have } \\
\text { accomplishe } \\
d \text { what they } \\
\text { set out to } \\
\text { achieve. }\end{array}$ & $\begin{array}{l}\text { Explain and } \\
\text { justify ideas } \\
\text { and } \\
\text { outcomes. }\end{array}$ & $\begin{array}{l}\text { Evaluate the } \\
\text { effectiveness } \\
\text { of ideas, } \\
\text { products, } \\
\text { performance } \\
\text { s, methods } \\
\text { and courses } \\
\text { of action } \\
\text { against given } \\
\text { criteria. }\end{array}$ & $\begin{array}{l}\text { Explain } \\
\text { intentions } \\
\text { and justify } \\
\text { ideas, } \\
\text { methods and } \\
\text { courses of } \\
\text { action, and } \\
\text { account for } \\
\text { expected } \\
\text { outcomes } \\
\text { agaianst } \\
\text { criteria they } \\
\text { have } \\
\text { identified. }\end{array}$ & 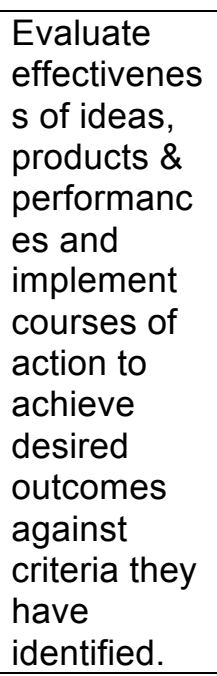 \\
\hline
\end{tabular}

\section{Seeking acceptance and agreement for a standardised information literacy framework}

Langford (1998, p. 53) asserts that information literacy, 'a process-oriented continuum of skills', should become 'part of the natural discourse of teachers as they design and develop 
curriculum units or discuss pedagogical issues. This discourse began with a series of workshops and formal discussions with teaching staff to encourage whole-school engagement and acceptance of the Integrated Information Literacy Plan. Many staff were not aware of the Information Process and had not closely interrogated the new Australian Curriculum. These workshops had the added benefit of providing a rich professional development opportunity for staff that they would not have otherwise had. Staff were invited to envision a scenario where information literacy, a fundamental literacy of the $21^{\text {st }}$ century, is inherent in the curriculum program with a common framework and a common language. $A$ year-by-year scope and sequence with agreed upon frameworks, organisers, and rubrics would ensure all students developed essential information skills that are mapped to curriculum outcomes. The response overwhelmingly from these workshops was that this scenario was welcome, essential, and long-overdue.

\section{Harnessing technologies to transform learning}

Technologies have a significant presence at lona Presentation College (with the one-to-one laptop program and the accompanying infrastructure support mechanisms) so it was important that part of the review process was to examine how well the school was using ICTs in pedagogically appropriate ways. While it was agreed and acknowledged that Information and Communication Technologies (ICTs) have the potential to extend student learning capabilities, engaging them in understanding concepts and processes in areas of learning, and facilitating change in learning, thinking and teaching, there was little if any evidence of this occurring in most learning areas. Internet searching and written reports dominated curriculum activities with some use of digital video. The opportunity was taken, during the professional development workshops to model and showcase a range of technologies to illustrate how they could be embedded into the teaching/learning program. Examples included using Scoop.it and Evernote for content curation, Book Creator on the iPads for the production dynamic, information products, and iBook Author for multi-modal books.

Collaborative online leaning spaces (Padlet) were used in the workshop when teachers were brainstorming so they could immediately see how this tool could be used in the classroom. Showcasing a range of websites and collaborative learning spaces (Collaborize and Edmodo) also allowed teachers to see the powerful potential of learning platforms such as these.

\section{Taking Action}

Feedback after the workshops indicated there was an ad hoc disjointed approach to teaching information literacy skills with no consistency in pedagogical approaches or resources. It also showed that learning technologies were not being used to their full potential to transform and enrich the learning process. Since these workshops, teachers have sought support to introduce a range of ICT tools into their lessons resulting in positive collaborative teaching opportunities. These workshops were definitely a springboard for the iCente's teacher librarians to take a leadership role in curriculum innovation in the College

With the Integrated Information Literacy Plan gaining wide acceptance from the academic staff and the learning team (teacher-librarians) from the iCentre now seen as key facilitators of this process, the next stage was to formalize the agreed information literacy framework, translate it into achievable skills/outcomes embedded within the curriculum, and generate a range of standard templates and proformas that would assist teachers and students in the demonstration of these skills. This would create a transparent process, with a common language and delivery platform to support the plan. Coupled with this would be a more strategic approach to integrating technologies into the teaching/learning program using information literacy as a key mechanism to achieve this.

The Inspired Learning website - not just a resource repository

A pre-disposition to life-long learning was identified as one of the $21^{\text {st }}$ century learning constructs essential in our curriculum. It does not have a subject of its own but relies on 
carefully developed strategies and processes being put in place at the school. According to Dave (1976) the school environment is critical in laying the foundations for life-long learning skills, such as learning to learn, positive attitudes toward learning, and striving for competency and excellence. Unfortunately for many schools the overloaded curriculum, results-driven agendas, and lack of support to promote a transformational curriculum means that many schools are unable to create this type of environment.

The Inspired Learning at lona website was initially created as the main response to the review process undertaken as part of The Plan, becoming a rich repository of carefully selected and created resources to support the information literacy program. It has, however, also evolved into a mechanism to promote and nurture the pre-dispositions necessary to become life-long learners (e.g. modules on metacognition, wellness, and study skills). While resources and support mechanisms were present in the College to nurture and encourage students in these affective domains, they were not organised in a logical way or easily accessible. They are now readily accessible 'at point of need' on the Inspired Learning website. Their presence online in and of itself sends a message that the College believes in the importance of these skills and now teachers, students, and parents alike have access to high quality resources that have been specifically chosen to encourage, engage, and inspire students to participate in behaviours conducive to life-long learning.

The website has also provided opportunities for ICT to be seen both as a learning environment and a means for learning. Text, images, video, podcasts, interactive images, and mashups have not only been used on the website to deliver information to students, they also showcase the many ways that technologies (Web 2.0 tools in particular) can be used in innovative and motivational ways to present information. Many examples have been student generated. This has already had an impact on the ways students are rethinking the presentation of their work. Their exposure to these technology tools in a pedagogically appropriate ways is no longer dependent on the teachers' own technology expertise. They have access to carefully selected, contextualised examples that encourage excellence and challenge their thinking 'anywhere, anytime'.

Table 3 describes the main modules on the Inspired Learning website. The resources in each module have been sourced, created and modified by appropriate teachers in the school. For example the essay writing templates that have been developed reflect the needs of the English Department but can then be used by any other Department where essay writing is required; all teachers will use the graphic organiser template suite; the resources in the wellness section have been sources by the school psychologist and home economics department. The website has been presented to staff, students and parents as an evolving support platform for student learning. Teacher and student contributions to the website also ensured that it was 'owned by the whole school community and was not just the providence of the iCentre.

Table 3: Elements of the Inspired Learning Website

\begin{tabular}{|l|l|}
\hline \multicolumn{1}{|c|}{ Elements } & \multicolumn{1}{c|}{ Description } \\
\hline iCentre & $\begin{array}{l}\text { Information about iCentre } \\
\text { Links to library system and online databases } \\
\text { Pathfinders }\end{array}$ \\
\hline $\begin{array}{l}\text { The Research } \\
\text { Process }\end{array}$ & $\begin{array}{l}\text { Details the step by step process for undertaking } \\
\text { research. Standard templates, process, and rubrics } \\
\text { provided }\end{array}$ \\
\hline $\begin{array}{l}\text { Learning to } \\
\text { Learn }\end{array}$ & $\begin{array}{l}\text { Brain Buzz } \\
\text { Learning Styles }\end{array}$ \\
\hline
\end{tabular}




\begin{tabular}{|c|c|}
\hline & $\begin{array}{l}\text { Memory Training } \\
\text { Mindmapping } \\
\text { Habits of Mind }\end{array}$ \\
\hline Study Skills & $\begin{array}{l}\text { Good Study Habits } \\
\text { Organisational Skills } \\
\text { Goal Setting } \\
\text { Time Management } \\
\text { Effective Revision } \\
\text { Preparing for exams }\end{array}$ \\
\hline Wellness & $\begin{array}{l}\text { The art of happiness } \\
\text { Diet } \\
\text { Exercise } \\
\text { Relationships } \\
\text { Sleep } \\
\text { Stress Management } \\
\text { Understanding Depression } \\
\text { Relaxation } \\
\text { Resilience }\end{array}$ \\
\hline $\begin{array}{l}\text { Learning with } \\
\text { Technology }\end{array}$ & $\begin{array}{l}\text { Staying safe online } \\
\text { Cybersafety } \\
\text { Technology Tools }\end{array}$ \\
\hline $\begin{array}{l}\text { Subject } \\
\text { Resources }\end{array}$ & $\begin{array}{l}\text { All learning areas have a resource page that has } \\
\text { been developed to reflect its unique nature and } \\
\text { requirements. }\end{array}$ \\
\hline Toolbox & $\begin{array}{l}\text { Essay writing } \\
\text { Graphic Organisers } \\
\text { Digital Storytelling }\end{array}$ \\
\hline
\end{tabular}

\section{Conclusion}

The Inspired Learning at lona website at lona Presentation College is the culmination of two years of strategic planning by the iCentre and its professional team. Coupled with the Integrated Information Literacy Plan it incorporates a whole school approach to the development of information literacy skills, ICT competencies and promotes the predisposition to become a life-long learner. It has been informed by, and encapsulates, many of the key themes, core principles and strategic frameworks that underpin not only the education program at lona Presentation College but also the current Australian and international educational landscape.

Some of the strategies that have been adopted to accommodate the changing learning landscape include:

- Re-imagining the school library as an inquiry centre (iCentre), where enabling the information-to-knowledge journey of students (central to school education) is also central to the professional role of the school librarian;

- Creating an online presence through the Inspired Learning at lona website that promotes information literacy, reflects current pedagogical thinking and showcases the technology-infused learning outcomes achieved by students as part of their educational program;

- Accommodating the evolving needs of learners by providing 'anywhere, anytime' access to rich resources that support their learning as well as modelling sound ethical on-line practices through the website;

- Developing a knowledge building environment that encourages students to question and extend their thinking beyond normal expectations; 
- Focusing on personalisation by accommodating different learning styles through a multi-literacy approach as well as providing students with examples of the many ways they can demonstrate their understandings;

- Exploring innovative ways of using the physical and virtual spaces that are the responsibility of the iCentre;

- Trialling and showcasing evolving learning devices whether it be mobile devices such as iPads and Apple TV, or the use of a range of Web 2.0 tools in their curriculum application; and

- Exploring the affordances of evolving pedagogies (including the flipped classroom, independent, differentiated and negotiated learning, and rich learning tasks that

The Big Blue Project Final Report indicates that library and academic staff working collaboratively produces the most successful integrated literacy skills programs, tying learning and assessment as closely as possible to the curriculum. Iona Presentation College recognises that information literacy is most effectively learned when it is relevant and contextualised - delivered, embedded, and assessed within the curriculum. Teachers and library staff work together to develop resource rich learning opportunities that incorporate a developmental scope and sequence of skills. This has eventuated in the creation of Pathfinders, websites, and blogs being created and teacher librarians and classroom teachers collaboratively teaching units of work. New technologies have also been a catalyst for classroom teachers seeking out and using the expertise of library staff to teach both themselves and their students how to integrate the ICTs into their lessons.

A knowledgeable and committed library staff, and a well-aligned Principal and teacher librarian leadership team support an effective school library. The school Principal at Iona Presentation College has championed the re-visioning of the iCentre. The teacher librarians at the iCentre were carefully selected by the Principal to support the school's future directions. They reflect a balanced approach to library management, literature and literacy, learning technologies, and information literacy. Roles have been carefully matched to areas of expertise and interest to ensure all aspects of the library program are well accommodated. The library staff work to:

- ensure information literacy is at the core of the curriculum programs developed;

- become leaders in innovative and pedagogically appropriate ways to use ICT;

- facilitate student collaborative learning in an innovative environment, and

- provide different learning environments for innovation and creativity.

\section{The Last Word}

Visionary leadership, a committed and experienced library team and a culture of collaboration and community are key components that have resulted in this innovative approach to ensuring the needs of the $21^{\text {st }}$ century students are being addressed at lona Presentation College. While there is cautious optimism about the success of the plan so far, capacity building and project sustainability will be the focus of the next stage of this curriculum initiative.

\section{References}

Australian Curriculum and Reporting Authority (ACARA.) (2011). General capabilities. Melbourne: ACARA. Retrieved 10 June, 2013, from http://www.australiancurriculum.edu.au/GeneralCapabilities/Overview/Generalcapabilities-in-the-Australian-Curriculum

ALIA. (2001). Learning for the future: developing information services in schools, 2nd ed., Carlton South, Vic: Curriculum Corporation. 
ALIA. (2003). Standards of professional excellence for teacher librarians. Retrieved 10 June, 2013, from http://www.asla.org.au/policy/standards.htm

Dave, R.H. (1976). Foundations of Lifelong Education. UNESCO Institute for Education.

Langford, L. (1998). Information literacy. In The information literate school community: Best practice. eds. J. Henri \& K. Bonanno (199). Centre for Information Studies, Wagga Wagga, N.S.W: Charles Sturt University.

MCEETYA Performance Measurement and Reporting Taskforce (2005), An Assessment Domain for ICT Literacy: Carlton South. Ministerial Council on Education, Employment, Training and Youth Affairs (MCEETYA).

Mcllvenny, L. (2013). Critical and Creative Thinking in the new Australian Curriculum. Access. $27(1), 18-22$. 